\title{
Teaching and illustrating the exegetical method of St Jerome: Letter 21 as a case study
}

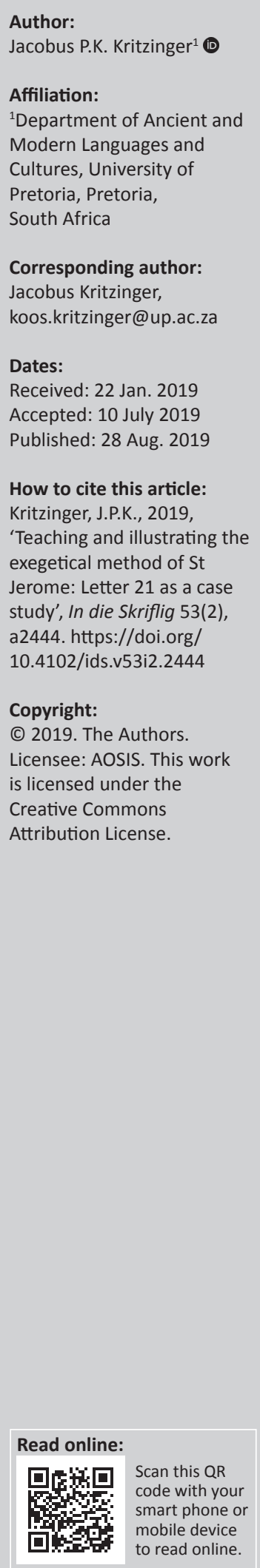

This article is intended as a case study to introduce students to the life and work of St Jerome, and more specifically to his exegetical method. Letter 21 to Pope Damasus contains Jerome's interpretation of the parable of the Prodigal Son and offers the ideal text to read with third year or honours Latin students. Since Professor Dircksen has a special interest in the teaching and learning of Latin, this contribution is meant for that section of the Festschrift. My aim is twofold: firstly, to offer an introduction to the text, focusing on several aspects which illustrate Jerome's exegetical method; and secondly, to illustrate how this material can be presented to students. Students are introduced to a well-known patristic author's approach to a biblical text, but in this process, they are taught how to approach any text themselves.

Keywords: St Jerome; Parable of the Prodigal Son; 'Letter 21'; Ancient languages; Patristics; Theology.

Letter 21 of St Jerome ${ }^{1}$ was written to Pope Damasus towards the end of 383 cE (Mierow \& Lawler 1963:224). It contains Jerome's reply on certain questions of Damasus about the interpretation of the parable of the Prodigal Son. In his reply, Jerome gives a full exposition of the whole Lucan passage, and this letter can thus be regarded as a commentary on the parable. ${ }^{2}$ In this article, I present an overview of Jerome's treatment of this parable and focus on the exegetical method, which he followed in Letter 21. There are several reasons why this letter deserves a closer look. By reading and studying this text, we can introduce students to the author and his works in a special way. ${ }^{3}$ It will provide insight into Jerome's exegetical method and introduce us to patristic exegesis in general. This letter also addresses theological issues of his day, which are still relevant today, such as the issue of the Law and Grace and the relationship of Christians towards the Jews and the Gentiles. Another interesting topic which is treated in this letter, is Jerome's attitude towards the Classics. Since Professor Dircksen has a special interest in the teaching and learning of Latin, I would like to present this contribution to the Festschrift as a case study for the teaching of the exegetical method of Jerome to Latin third year or Honours students. My aim is thus twofold: firstly, I want to offer an introduction to the text, focusing on several aspects which illustrate his exegetical method; and secondly, I want to illustrate how this material can be presented to students. The two aspects will be dealt with simultaneously.

At the beginning of the module, students ${ }^{4}$ are asked to read chapter 15 of the Gospel of Luke in translation and to think about the interpretation of the text. They are encouraged to formulate a few critical questions. During the first meeting these questions will be briefly discussed. The discussion will mainly be determined by the questions of the students, but if there are other questions which they did not consider, the lecturer could put forward additional matters, for example What is the relationship between the three parables told in this chapter?; Why does Jesus (or Luke) tell these parables?; What is a parable?; Who is the first audience?; Do we know who the first addressee of the Gospel of Luke is?; and more. The purpose of this meeting is not to answer or attempt to answer the questions, but to indicate the importance of asking questions to the text.

\section{The Latin text of Hilliberg (1910) is used.}

2.See Scheck (2010) for Jerome's commentaries on complete books of the New Testament. According to Williams (2006:66) '[t]he greatest achievement of Jerome's career as a biblical scholar was his commentaries on the Hebrew prophets'.

3.An overview of Jerome's life and works will be given at the beginning of the course. The book of Rebenich (2002) can be recommended. For a detailed account of Jerome as letter writer, see Conring (2001). See also Kritzinger (2010:77-95) for Jerome on letters and letter writing.

4.There are often one or two theology students in the Latin third year or Honours classes, and this module could be of special interest to them, but it is not only meant for theology students. It will be emphasised that this is just another Latin text from a later period, which we read and analyse in its specific context - it is not a theology module.

Note: This contribution is collected as part of the 'Marianne Dircksen Festschrift', sub-edited by Johan Steenkamp (North-West University). 


\section{Introduction to the letter}

During the second meeting, students are introduced to the author and his work. An overview of Jerome's life and works is given, focusing on his letters and commentaries on the Bible. From the third meeting the Latin text of Letter 21 is read and discussed in class. Letter 21 has a very simple structure: paragraph 1 is the introduction with the request of Damasus; paragraphs 2-3 explain the context of the parable and state the basic issue which Jesus addressed here; paragraphs 4-41 contain a verse by verse commentary on Luke 15:11-32 and paragraph 42 is a short conclusion. ${ }^{5}$ The first three sentences of the introduction are very important for students to understand the description and evaluation of Jerome's exegetical method, and therefore we have to examine it closely. In these opening lines Jerome explains the reason for writing this letter and says that he has done it at the request of Pope Damasus. ${ }^{6}$ It is clear that he has respect for Damasus and compliments him on asking the right questions. He starts his address to Damasus on a high rhetorical note with the following three short statements: ${ }^{7}$

Beatudinis tuae interrogatio, disputatio fuit: et sic quaesisse quaerendo viam est dedisse quaesitis. Sapienter quippe interroganti, sapientia reputabitur. ${ }^{8}$ (Ep. 21.1.1)

In these three sentences he shows off his rhetorical skill by generously using homoeoteleuton (interrogatio; disputatio; quaesisse, dedisse) and polyptoton (interrogatio and interroganti; quaesisse, quaerendo and quaesitis; sapienter and sapientia), which necessarily results in a sound play of assonance and alliteration. The prominence of words of asking (interrogatio; quaesisse; quaerendo; quaesitis and interroganti) emphasises the questions of Damasus, which introduce Jerome's commentary on the parable. No less than 10 questions are mentioned in the rest of the introduction and they provide a starting point for Jerome's discussion of the parable, which proves his statement that 'to have posed questions thus is to have opened a way for a reply'. There is a progression in the tenses of the verbs: from past (fuit) to present (est) to future tense (reputabitur). The second sentence, which is the longest of the three sentences, contains five verbal forms: two perfect infinitives (quaesisse and dedisse), a gerund (quaerendo), a finite verb (est) and a perfect participle (quaesitis). The two infinitives serve respectively as subject (quaesisse) and complement (dedisse) of the verb (est), linking

5.The lecturer could decide how much of the original tatin text should be read and the rest can be read in translation. My suggestion would be to read at least the following in the original: paragraphs 1-13 and paragraph 42.

6.Jerome addressed nine letters to Pope Damasus: letters 15, 16, 18A-18B, 19-21, 35-36. He served as secretary to Damasus from 382 until the end of 384 when Damasus died and Jerome left Rome in the fall of 385 to settle in Bethlehem (Mierow \& Lawler 1963:7).

7.'The question of Your Beatitude was a theme for argument, and to have posed questions thus is to have opened a way for a reply. Indeed, wisdom will be ascribed to one who questions wisely'. The English translation is that of Mierow (Mierow \& Lawler 1963) and is used for all the quotations from Letter 21 in this article. This older translation is used on purpose, for students are expected to make their own translation during the course and are also encouraged to make use of other available translations. Students will be challenged to create fresh dynamic translations in which the meaning has preference over a direct word-for-word translations

8.According to Lawler (Mierow \& Lawler 1963:224 n.2), the last sentence is possibly an allusion to Proverbs 17:28: 'Even a fool, if he will hold his peace shall be counted wise: and if he close his lips, a man of understanding'. two actions (asking and giving) which are normally used as opposites. One of the functions of an introduction is to gain the goodwill of the audience or addressee and this flattering praise of Damasus as a wise man (Sapienter ... sapientia reputabitur), can be regarded as a good example of such a captatio benevolentiae. ${ }^{9}$ It is important to know who the addressee (or audience) is to whom a work has been addressed. That provides us with a better understanding of the context in which it was written. We know that Damasus is the primary addressee of this letter, but the work was certainly also meant for wider distribution. ${ }^{10}$

Jerome then proceeds with a list of questions that Damasus has put to him (his interrogatio). He starts with general questions (in the direct speech) related to the interpretation of the parable:

Who is the father? Who are the two sons? How does the younger one squander his inheritance with prostitutes? What does it mean that he was sent to look after the pigs and that he ate their pods, that he returned to his father, received a ring and a robe and that the fattened calf was killed for him? Who is the older brother and why is he jealous of his brother on his return? (Ep. 21.1.1)

These questions almost cover the interpretation of the whole parable. After the general questions, Jerome again quotes Damasus, describing and discussing the specific problems of the identification of the older brother with the Jews and the younger brother with the Gentiles, or with the righteous and the sinner respectively. These questions of Damasus confront Jerome with different interpretations of the parable, and introduce the difficulties that accompany these interpretations. A very important principle of text analysis is introduced here, viz. to ask the right questions to the text. ${ }^{11}$ Jerome does not reply with a straightforward answer. His first remark refers to a methodological step. He says:

Therefore, as we are accustomed in the other parables which were not explained by the Saviour to inquire why they were spoken, so we should do also in the case of this. Why did the Lord give utterance to such words? Because of what question was this kind of reply given? (Ep. 21.2.1)

Jerome provides the answer to these questions by referring to the scribes and Pharisees who wanted to know why Jesus receives sinners and eats with them. With this question, Jerome puts the parable in context by enquiring about the reason why Jesus told this parable. The question about the Sitz im Leben [setting or context of the specific passage] is an essential step in the exegetical process, and Jerome states here that he usually asks (solemus inquirere) why the parables were told. Jerome first refers to Luke 15:1-2, but he also

9.For an interesting article on the function of the captatio benevolentiae, see Andoková (2016).

10.In a note on 'Fidelis ... lector' (para. 26.2), Lawler (Mierow \& Lawler 1963:230 n.113) states: 'Jerome was perhaps aware of the wide circle of readers his commentary would reach'.

11.Students should get the opportunity to discuss this in class and should be prompted to formulate typical questions which the reader, interpreter or commentator should ask. The questions which the students have formulated after their first reading of the parable, can also be compared to the questions of Damasus. 
quotes from Matthew 9:10-13 and says that Mark 2:15-17 agrees and uses the same language. Another important exegetical principle is illustrated here and in the rest of the letter, ${ }^{12}$ namely to explain one biblical passage by referring to other passages where the same issue is discussed, or which at least seems relevant to the commentator. Jerome refers to the envy of the scribes and the Pharisees and explains the reason behind it: 'Therefore, all their envy has this source: the question why the Lord did not avoid speech and intercourse with those whom the precepts of the law condemned' (Ep. 21.2.2). In the Matthew and Mark passages the same question about Jesus eating with publicans and sinners is asked, but the answer is not the same. In both instances Jesus replied as follows:

They that are in health need not a physician, but they that are ill. Go then and learn what this meaneth: I will have mercy and not sacrifice. For I have not come to call the just, but sinners. (Ep. 21.2.2)

From this, Jerome concludes that this whole issue arose out of the law and then expands on the contrasts of law versus mercy, and forgiveness versus punishment. Jerome discusses this issue at great length and refers to several other biblical passages (Ps 13:3; Rm 1:7; 3:12; 5:20; Gl 4:4; Eph 2:14; 1 Jn 2:2, etc.) to prove the priority of grace over the law. This is a crucial part of the letter in which Jerome summarises the central message of the gospel, namely that God has sent his Son to save sinners whom he called to repentance and 'tempered the severity of the law by the grace of the gospel' (Ep. 21.2.3). He concludes this line of argument by stating that Jesus has told these three parables to refute the accusation of the scribes and the Pharisees. He makes it clear that the three parables (on the lost sheep, on the lost coin, and on the lost son) serve the same purpose, but that he will focus on the third one, which he was asked to explain. The demarcation of pericopes forms an important step in the exegetical process and even though it is not stated explicitly here, it's clear that Jerome indicates the different pericopes and then announces his intention to focus on the third parable. Although this might seem unimportant, students should be made aware of the fact that there can be different pericopes in a chapter and that there are specific markers which indicate separate units, et cetera. Jerome describes the purpose of these parables as follows:

Let it suffice to say only this much, that these parables were set forth for this purpose: as in the finding of the sheep and of the groat there is joy of the angels and of the neighbors round about, so at the repentance of publicans and sinners there should be joy on the part of all who have no need to repent. (Ep. 21.3.1)

He thus identified the main theme of the parable as an issue about 'law versus grace', and this identification directly results from his discussion of the context. Another prominent theme which he addresses here, is that of 'envy versus joy'.

In the rest of paragraph 3, Jerome criticises Tertullian's interpretation of this passage. Tertullian was of the opinion that 12.See Mierow and Lawler (1963:224-232) for the long list of biblical references in Letter 21. the publicans and sinners mentioned here were not Jews. Jerome differs from him and motivates his position again with references to several biblical passages. He points out that Matthew, the publican, was of the circumcision, that is, a Jew, and that the publican who prayed with the Pharisee in the temple was also a Jew. It brings him to the conclusion that 'publicans' here refers to all sinners generally, those who were Gentiles and those who were Jews. Tertullian defended the dogma according to which penitent Christians should not be taken back. ${ }^{13}$ In his criticism on Tertullian, we can see how Jerome approaches the work of other commentators and how he argues his case with arguments from the Bible. In this short passage, we also get an idea of Jerome's polemical style: he often launches personal attacks and does not hesitate to insult his opponents. Here he describes Tertullian as 'that man who defended that dogma before his mad and blasphemous women'. ${ }^{14}$

\section{Verse-by-verse commentary}

The last sentence of paragraph 3 is a transitional sentence, which connects the introduction (paras. 1-3) to the verse by verse commentary, which commences in paragraph 4 :

Therefore, not to make a long story of it, ${ }^{15}$ I shall set forth the very words of the Gospel and like a commentator subjoin my interpretation to each passage. (Ep. 21.3.3)

There are minor differences between the ipsa evangelii verba, that is, the text, which Jerome quotes here, and the Vulgate (see Mierow \& Lawler 1963:226-228). Brown (1992) makes the following remark regarding Jerome's approach to the text:

It is quite clear that Jerome knew that the first task of the exegete was to establish the biblical text on which he was to comment. We have seen how Jerome, to an even greater degree than his predecessor, Origen, or any other Christian father, was aware of the pre-existing principles of textual criticism, and that Jerome used these principles to his best advantage to ensure that the text on which he was to comment was as close to the original manuscript as possible. (p. 195)

That would not be possible without a good command of the original languages of the Bible, Hebrew ${ }^{16}$ and Greek. ${ }^{17}$ In this

13.Note, however, Lawler's (Mierow \& Lawler 1963:225) remark in this regard Regarding the adversum paenitentiam, it should, of course, be recalled that Tertullian did not oppose all repentance and penance, and that there was a distinction in his theology between "remissible sins" and sins which were considered to be "irremissible" (i.e. by the Church, not by God)'.

14.Ep. 21.3.3: 'Ille autem qui juxta insanas et blasphemas feminas suas, id dogmatis defendebat, quo Christianos nollet recipere poenitentes, ...'. For a fuller picture of Jerome as satirist and polemicist, see Wiesen (1964).

15.The requirement of brevity in letter writing is a literary topos. According to Julius Victor's, Ars Rhetorica (Giomini \& Celentano 1980:105), brevity is the first rule to follow in the case of private letters: 'In familiaribus litteris primo brevitas observanda'. See also the remarks of Cain (2009:83) on the precept of epistolary brevitas.

16.See also Newman's contribution, 'How should we measure Jerome's Hebrew competence?' in Cain and Lössl (2009:131-140) for a critical evaluation of Jerome's knowledge of the Hebrew language.

17.The title, Vir trilinguis, which Brown uses in his book on Jerome as an exegete, 'Vir trilinguis: A study in the biblical exegesis of Saint Jerome', refers to Jerome's command of the three biblical languaes - the third langua , being his mother command of the three biblical languages - the third language being his mothe tongue, Latin, into which he has translated large parts of the Old and New Testament. Jerome refers to himself as vir trilinguis in Apol. c. Rufin. 3.6: 'Ego philosophus, rhetor, grammaticus, dialecticus, hebraeus, graecus, latinus, trilinguis'. See also Rebenich (1993). King, in Cain and Lössl (2009:209-223) discusses Jerome's knowledge of Aramaic or Syriac and the title of his chapter is 'Vir quadrilinguis? Syriac in Jerome and Jerome in Syriac'. 
regard, Jerome's expertise as Bible translator was certainly his claim to fame and his Latin translation of large parts of the Bible from the original Hebrew and Greek is regarded as his opus magnum. In paragraph 6, Jerome refers to the Greek version of Luke 15:12 and says that the Greek reading $\delta 1 \varepsilon i \tilde{\lambda} \varepsilon v$

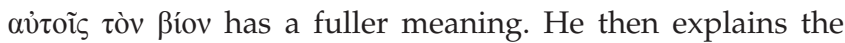
meaning of the Greek word, Bíos, which is translated in Latin by substantia, and uses the opportunity to promote his view of the free will of man and the accountability which results from it:

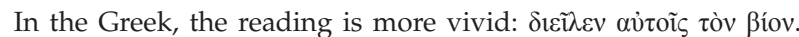
That is, he gave them free choice, he gave their hearts' desire, that each might live, not in accordance with God's command, but to please himself; that is, not out of necessity, but by free will, in order that virtue might have its place, so that, like God, we have the privilege of doing what we wish, differing in this from all the other animals. (Ep. 21.6)

Paragraph 29 is a very short paragraph in which he refers to the Hebrew, Greek and Latin meanings of a specific word. It is a good example of Jerome's reference to the meaning of Hebrew and Greek words in his commentaries. ${ }^{18}$ It reads as follows:
'And when he came, he drew nigh to the house and heard music and dancing.' The superscription of a certain Psalm, 'for Maheleth', is in accord with this meaning, because meleth is said of a harmonious chorus. It is a mistake when some Latin interpreters suppose a symphony to be a kind of organ; because the concordant harmony in God's praise is expressed by this word: symphonia is represented in Latin by consonantia. (Ep. 21.29)

To return to the verse-by-verse commentary: he opens this section with the quotation of Luke 15:11 ('A certain man had two sons'), followed by his discussion of that verse. This pattern is then followed for the next 37 paragraphs. The verse-by-verse commentary cannot be discussed at great length. Only a few specific points are highlighted, which are relevant in order to illustrate his exegetical method. ${ }^{19}$

Jerome's interpretation of Luke 15:16 (para. 13) illustrates his allegorical exegesis of this verse. Firstly, it must be said that commentators in general tend to resort more easily to allegorical interpretations in the case of parables - in a certain way the fact that a parable is a story with a deeper meaning, makes the temptation to ascribe a specific deeper meaning to almost each and every word so much stronger. ${ }^{20}$ In this verse it is said that the younger son wished to fill his stomach with the husks of the pigs, but that no one gave it to him. Jerome states that the husks of the pigs refer to the food of demons, which are drunkenness, luxury, fornication and all other sins. He also describes this sinner's situation as a fulfilment of a

18.There are more examples of references to the meaning of Greek and Hebrew words, for example in paragraph 8 where he explains the meaning of the place name, Naid, (which he interprets as 'wandering'), and Babel (meaning 'confusion').

19.Students can, during the course, be asked to consult a modern commentary on this Lucan passage and to compare it with Jerome's work.

20.Cf. Kelly (1975:146): 'The exegesis itself, usually derivative, varies in character with the source used as well as with the material commented on. On Philemon and Titus, where the subject-matter scarcely lend itself to allegory, it is mostly practical and to the point' prophecy of Ezekiel 16:33, which he quotes: 'Gifts are given to all harlots; but thou hast given hire to all thy lovers and didst not take rewards' (Ep. 21.13.3). Here again we notice Jerome's practice of linking the current passage to another biblical passage which bears some resemblance, in this case within the prophecy-fulfilment scheme. Jerome then continues to add an alternative interpretation in which he interprets the husks of the pigs as the food of the demons which is the songs of poets, secular wisdom and the display of rhetorical language, things which cannot still the hunger for the truth (Ep. 21.13.4).

Jerome then mentions a theme which was very relevant at that time, namely the Christian's use of the pagan classics. This concerns him personally, as he has also been accused of being a Ciceronian rather than a Christian. ${ }^{21}$ In the rest of paragraph 13, he comes up with an exegetical 'trick' to solve his dilemma. He refers to Deuteronomy 21:10-13 where certain precepts are given to any Jew who wants to take a non-Jewish woman as a wife. In this case, he prefers to see the figure of a captive woman as a type of secular wisdom and believes that this passage should not be interpreted literally. In a rhetorical 'nonne-question' he makes it clear that a literal interpretation of this passage is ridiculous:

A type of this sort of wisdom is described in Deuteronomy under the figure of a captive woman. The divine voice commands that if an Israelite desires to have her as a wife, he shall make her bald, pare her nails, and shave her hair. When she has been made clean, then she shall pass into the victor's embrace. If we understand that literally, isn't it ridiculous? And yet we ourselves are accustomed to do this when we read the philosophers, when the books of secular wisdom come into our hands. If we find anything useful in them, we apply it to our own doctrine; but if we find anything - with regard to idols, love, the care of secular things - that is inapplicable, these we shave off, for these we decree baldness, these we cut away like our nails with a very sharp blade. (Ep. 21.13.5-6)

Apart from demonstrating Jerome's treatment of the text, this excerpt also illustrates that in his exegesis he relates the message of the text to burning issues of his day, which makes the exegesis more relevant. Another characteristic of Jerome's exegetical method, which is illustrated here, is the fact that he often provides more than one explanation without indicating which interpretation he prefers. What is also important is his belief that the literal sense is not always valid and then the spiritual or allegorical interpretation provides the only viable interpretation. The word, typus, which Jerome uses here, is a technical exegetical term..$^{22}$ It normally indicates something in the Old Testament, which points to, or foreshadows something greater, or more important in the New Testament. The Alexandrian exegete Origen, was a champion of allegorical exegesis and had a great influence on Jerome..$^{23}$ After studying Jerome's usage of the literal sense in his 21.In his famous Letter 22 , this issue is further discussed in detail. 22.For Jerome's technical vocabulary, see Brown (1992:142-151).

23.For a discussion of Jerome's commentaries on the epistles of St Paul, and Jerome's dependence on the work of Origen, see Chapter 15 of Bammel (1995) and Vessey (1993). 
exegesis, Brown (1992:197) concludes that according to Jerome, the plain interpretation should be given first, and a spiritual or allegorical meaning was only to be sought if the meaning implicit in the passage was not exhausted by the literal sense. In his allegorical interpretation of Luke 15:23 (para. 26), the fatted calf that has to be killed, refers to Jesus. He further links this verse to Psalm 45:2, which he interprets as a Messianic Psalm:

The fatted calf, which is sacrificed for the safety of penitents, is the Saviour himself, on whose flesh we feed, whose blood we drink daily. My believing reader, you understand with me with what fatness we have been filled that we burst forth to the utterance of His praises, saying: My heart hath uttered a good word, I speak my words to the king; although some - superstitiously rather than truly, and not considering the text of the Psalm think this is to be understood of the Person of the Father. ${ }^{24}$ (Ep. 21.26.1-2)

Apart from the allegorical exegesis, we see here also an example of Jerome's Christocentric approach to not only the New Testament, but also the Old Testament. In this same paragraph, Jerome confirms the close connection with the previous parables when he states that the interpretation is the same in this case as in the two preceding parables. There it is mentioned specifically that the angels of God rejoice over one sinner who repents. In the first two parables with the sequence, lost - found - celebration, the joy is explicitly compared to the joy in heaven over the repentance of one sinner. Although there is the same sequence in the parable of the two sons, the biblical author did not find it necessary to mention again the fact that there is joy in heaven over the repentance of a sinner. It is certainly obvious from the context and Jerome, who views these parables as a close unit, knows that it is important for the interpretation of the whole.

Next we look at paragraph 28 in which he comments on Luke $15: 25$. In this paragraph, a summary is given concerning the question about the identity of the younger and older brother. He says that the younger son refers to the publicans and sinners who were called by the Lord to repentance. Then he adds that, according to the mystical interpretation, it is also a prophecy concerning the future calling of the Gentiles. Jerome uses the expression mystical interpretation as a synonym for the spiritual sense. He then continues by stating that some people interpret the older son as referring to the saints, while others correctly see him as pointing to the Jews. He argues the case and decides that the identification with the saints fits the description that he has never transgressed the Father's commandment, but the envy at his brother's salvation does not agree with the saints. The envy of the older brother, on the other hand is in line with the identification with the Jews; but the fact that he says that he has never transgressed his father's commandment, is not clear and he promises to return to it later. In paragraphs $34-35$, he then explains it by saying that the older brother is lying in self-justification; that he is boasting before God of his

24.Ironically, this verse from Psalm 45:2 is now generally interpreted as a Royal Psalm and according to its context, modern commentators do not connect it with either the Father or the Son. justice which, in itself, is a transgression of the law. These paragraphs clearly address the questions of Damasus mentioned in paragraph 1 , and proves the statement that Damasus' questions prepared the way for the answers. We see here how Jerome motivates his interpretation and argues against possible objections to his understanding of the text.

\section{The exegetical method}

The principles of Jerome's exegetical method can be summarised as follows:

- He valued the original text and knowledge of the biblical languages highly;

- he realised the importance of textual criticism and took care to establish the best text;, ${ }^{25}$

- he was an eclectic scholar and made use of the insights from different exegetical traditions, namely the Antiochene, Alexandrian and Jewish traditions (see Brown 1992:199);

- he mainly employed the allegorical method in this letter and generally regarded the spiritual sense superior to the literal sense, ${ }^{26}$ even though the literal sense was very important to him;

- he explained the Bible with the Bible. He knew his Bible very well, and if there was the slightest hint that another biblical passage could help to elucidate the matter at hand, he did not hesitate to quote and discuss it;

- he regarded the context of the specific passage of crucial importance for understanding the message of the text and in this letter, Jerome described the context very well;

- an important element in his work as exegete is the way in which he argued and motivated his interpretation, be it with references to other biblical texts, or through logical reasoning;

- he discusses the work of earlier exegetes and does not hesitate to differ from them, and

- he followed the non verba, sed sensus principle, which gives priority to meaning over words or style.

At the beginning of this letter, Jerome states that wisdom will be ascribed to him who questions wisely. In interpreting the Bible, it is indeed important to ask the right questions to the text, which would often lead to meaningful answers. I believe that Jerome, like Damasus, can also on this account be regarded as a wise man, because he has asked (and answered) wisely.

\section{Conclusion to the letter}

In the final paragraph (para. 42), Jerome introduces the principle which is also the motto of his theory of translation, namely that in ecclesiastical matters it is not words that

25.Cain (2010) says the following in this regard: "He [Jerome] operated under the assumption that before one can properly comment on Scripture, one needs a assumption that before one can properly comment on Scripture, one needs a reliable text with which to work. This point deserves further consideration here, distinguished biblical textual critic of the early church plying his trade ... (p. 36)'

26.See Brown (1992): 'A further point which must be made in relation to Jerome's esteem for the spiritual sense of scripture, is that for him, the spiritual sense is superior to the literal sense. This is a fundamental point for him, and he makes it consistently throughout his exegetical works (p. 152)' 
matter, but meanings. ${ }^{27}$ Jerome uses it here, together with his deteriorating eyesight and the fact that he has to dictate the letter, as an excuse for his unadorned style. He further compares the meanings with bread and the words with husks, clearly referring to the food of the pigs. Jerome says:

I have no doubt that this discourse of our insignificance seems crude to you. But I have often argued that a topic cannot be perfected without being polished by a proper hand. Therefore, pardon my smarting eyes - that is, forgive me for dictating especially since in ecclesiastical matters it is not words that are sought but meanings. That is, life must be sustained by bread, not by husks. (Ep. 21.42)

It is clear that his humility on account of the unpolished style, is a literary topos, which Kelly (1975:146) describes as 'conventional self-deprecation'. In his opening lines, Jerome starts on a high rhetorical note and refers to the request of Damasus with the words, Beatitudinis tuae interrogatio. In his closing paragraph, he refers to his reply with the words, nostrae parvitatis ... oratio. The high praise of Damasus in the introduction is balanced by Jerome's reference to the simple style of the letter ${ }^{28}$ and his own insignificance in the conclusion. In his final sentence he gives, as a last thought, his motto non quaerantur verba, sed sensus and balances it neatly with the chiastically arranged panibus ... non siliquis. The verb quaerantur reminds us again of the use of the verb quaero in the introduction, while his identification of the meanings (sensus) with bread (panibus) and the words (verba) with the husks (siliquis) recalls the commentary on the parable itself. But it also refers to the importance of the content (of Jerome's interpretation) rather than the form (style of his presentation). The expression panibus sit vita sustentanda and the placement of 'bread' and 'life' so close to each other, might further be an allusion to John 6:35 where Jesus is described as the Bread of Life. Ironically, Jerome apologises for his 'seemingly unsophisticated style' (inculta ... videatur oratio) in a carefully constructed and highly rhetorical ${ }^{29}$ conclusion.

\section{Final remarks}

The author of this article tries to kill two birds with one stone: to give an overview of Jerome's commentary on the parable of the Prodigal Son, and to present it as a case study for teaching and illustrating the exegetical method of Jerome. I hope to have proved that Letter 21 of Jerome is an ideal text to read with third year Latin or honours students in order to introduce them to the life and work of an exceptional patristic author, to his exegetical method, to patristic exegesis in general, to interesting issues of his day,

27.Jerome's theory of translation is explained in detail in Letter 57 , which is also known as Liber de optimo genere interpretandi. For a comprehensive commentary on this letter, see Bartelink (1980).

28.See Cain (2009:82-83) about Jerome's apology for his "use of the "plain style" in exegetical discourse' in Letter 36 to Pope Damasus.

29. Note the repetitions of: non ... sed ..., non ... sed ...; ignosce ... ignosce; id est ... id est ...; the chiastic arrangement of verba ... sensus... panibus ... siliquis, and the different ways in which he refers to his seemingly unadorned style: inculta ... oratio; expoliri non posse sermonem; nisi ... limaverit. such as the attitude of early Christian authors toward pagan classic literature, and much more. ${ }^{30}$ The fact that this letter is also a commentary, provides the additional bonus that two of the genres in which Jerome excelled, can be studied at the same time.

Apart from their preparation for lectures, which includes translation of the Latin text of Letter 21 and prescribed readings from secondary sources ${ }^{31}$ students are also expected to write an assignment on the life or work of Jerome, on patristic exegesis, or on any other topic related to the coursework..$^{32}$ For the final assessment, it is suggested that students prepare and deliver a 30 minute presentation ${ }^{33}$ in which they share the findings of their research assignment with their classmates. The purpose of these presentations is, in the first place to add content and variety to the coursework, but secondly, and perhaps more importantly, to provide students the opportunity to prepare and present a 'public' lecture and to encourage them to present research papers at conferences.

\section{Acknowledgement}

I would like to thank the anonymous reviewers and my colleague, Susan Haskins, for their valuable comments and helpful suggestions.

\section{Competing interest}

The author declares that no competing interest exists.

\section{Author contributions}

I declare that I am the sole author of this research article.

\section{Ethical consideration}

This article followed all ethical standards for carrying out research without direct contact with human or animal subjects.

\section{Funding}

This research received no specific grant from any funding agency in the public, commercial, or not-for-profit sectors.

\section{Data availability statement}

Data sharing is not applicable to this article as no new data were created or analysed in this study.

30.The scope of an article does not allow for an in-depth study of the letter, but the lecturer can identify specific passages in the letter to discuss more thoroughly, depending on the length of the course and the number of credits assigned to the module.

31.Especially from the books of Brown (1992), Rebenich (2002), Cain (2009) and Cain and Lössl (2009).

32.A wide variety of topics can be suggested by the lecturer, so that students can also choose from themes which were not discussed in class, e.g. Jerome as hagiographer; The presentation of Jerome in art; Jerome and Rufinus; Jerome and Augustine; Jerome's translation theory; Jerome and the women in his life; et cetera.

33.They will be encouraged to use PowerPoint or similar programs during their presentations. 


\section{Disclaimer}

The views and opinions expressed in this article are those of the author and do not necessarily reflect the official policy or position of any affiliated agency of the author.

\section{References}

Andoková, M., 2016, 'The role of captatio benevolentiae in the interaction between the speaker and his audience in Antiquity and today', Systasis 29, viewed 10 December 2018, from http://www.systasis.org/pdfs/systasis/29/1.pdf

Bammel, C.P., 1995, Tradition and exegesis in early Christian writers, Variorum, Aldershot.

Bartelink, G.T.M., 1980, Liber de optimo genere interpretandi (Epistula 57): Ein Kommentar, Brill, Leiden.

Brown, D., 1992, Vir trilinguis: A study in the biblical exegesis of Saint Jerome, Kok Pharos, Kampen.

Cain, A., 2009, The letters of Jerome: Asceticism, biblical exegesis, and the construction of Christian authority in late antiquity, Oxford University Press, Oxford.

Cain, A., 2010, St. Jerome: Commentary on Galatians, Catholic University of America Press, Washington, DC. (The Fathers of the Church).

Cain, A. \& Lössl, J. (eds.), 2009, Jerome of Stridon: His life, writings and legacy, Ashgate, Farnham

Conring, B., 2001, Hieronymus als Briefschreiber: Ein beitrag zur spätantiken Epistolographie. Mohr Siebeck, Tübingen. (Studien und Texte zu Antike und Christentum).
Giomini, R. \& Celentano, M.S., 1980, C. Iulius Victor: Ars rhetorica, De Gruyter, Leipzig. (Bibliotheca Scriptorum Graecorum et Romanorum Teubneriana).

Hillberg, I., 1910, Sancti Hieronymi Epistulae, Tempsky, Vienna. (Corpus Scriptorum Ecclesiasticorum Latinorum, vol. 54, F).

Kelly, J.N.D., 1975, Jerome: His life, writings and controversies, Duckworth, London.

King, D., 2009, 'Vir quadrilinguis? Syriac in Jerome and Jerome in Syriac', in A. Cain \& J. Lössl (eds.), Jerome of Stridon: His life, writings and legacy, pp. 209-224, Ashgate, Farnham.

Kritzinger, J.P.K., 2010, 'Jerome on letters and letter-writing', Scrinium 6, 77-95. https://doi.org/10.1163/18177565-90000039

Mierow, C.C., (transl.) \& Lawler, T.C., (Introduction \& notes), 1963, The Letters of St. Jerome, vol. 1, Letters 1-22, Newman Press, New York. (Ancient Christian Writers).

Newman, H.I., 2009, 'How should we measure Jerome's Hebrew competence?' in A. Cain \& J. Lössl (eds.), Jerome of Stridon: His life, writings and legacy, pp. 131-140, Ashgate, Farnham.

Rebenich, S., 1993, 'Jerome: The Vir trilinguis and the Hebraica veritas', Vigilia Christiana 47, 50-77. https://doi.org/10.2307/1584340

Rebenich, S., 2002, Jerome, Routledge, London. (The early Church Fathers).

Scheck, T.P., 2010, St Jerome's Commentaries on Galatians, Titus, and Philemon, University of Notre Dame Press, Notre Dame.

Vessey, M., 1993, 'Jerome's Origen: The making of a Christian Literary Persona', Studia Patristica 28, 135-145.

Wiesen, D.S., 1964, Saint Jerome as a satirist: A study in Christian Latin thought and letters, Cornell University Press, Ithaca, NY.

Williams, M.H., 2006, The monk and the book: Jerome and the making of Christian scholarship, University of Chicago Press, Chicago, IL. 